Graciliano Ramos: 120 anos 



\title{
Temposfuturos - Vidas secas, de Graciliano Ramos
}

\author{
ZENIR CAMPOS REIS
}

"La réalité sans possibilité réelle n'est pas complète".

(Ernest Bloch, Le principe espérance)

\section{Preliminares}

$\mathrm{C}$

ERTO CRÍTICO, anos atrás, me insinuara utilizar num romance os camponeses do Nordeste. Apesar de sertanejo, achava-me incapaz de fazer isso, e antes de viver com esses homens na cadeia, dormindo nas esteiras podres e dividindo fraternalmente os percevejos, não me arriscara a aceitar o conselho. (Ramos, 1955, p.128)

Esta breve referência à gênese de Vidas secas adverte o leitor a respeito das exigências a um tempo éticas e estéticas da escrita de Graciliano Ramos. Quando ele diz camponês ou sertanejo devemos entender os termos não em sentido genérico, mas no sentido preciso de camponês ou sertanejo pobre.

Sertanejos e camponeses não faltam em S. Bernardo ou em Anguistia: Casimiro, Marciano, José Baía, entre outros, figuram nesses livros, no entanto, isolados e em posição lateral. Vidas secas, de fato, será seu único romance em que toda uma família de sertanejos, sertanejos pobres, ocupará o centro da narrativa. ${ }^{1}$

Vistos pelo ângulo puramente ético, seus escrúpulos são semelhantes aos de muitos intelectuais, especialmente os de esquerda: geralmente de origem burguesa ou pequeno-burguesa, a adesão à causa proletária precede a experiência histórica. Mesmo os de origem "popular" manifestam muitas vezes o receio de falsear a experiência de origem, de trair involuntariamente a própria memória, individual ou de grupo.

Apanho, entre tantos possíveis, dois exemplos. O primeiro, contemporâneo, de Vasco Pratolini, escritor florentino de origem proletária que, num de seus contos, coloca na boca do narrador, espécie de porta-voz de suas próprias ideias:

Se eu atraiçoasse a vossa recordação no jogo de espelhos da memória, amigos, seria como se, esta noite, deitasse veneno no prato do meu pai. É preciso que transcreva as vossas palavras antes que dentro dos meus ouvidos as vozes se calem no sono. A caneta é o meu instrumento de trabalho, como o martelo pneumático para o homenzinho, que era mineiro, como a colher de trabalho para o parmense, que era pedreiro. A literatura é o meu pão, como o passeio para a rapariga prostituta, o contrabando para os seus três amigos do mercado negro. (Pratolini, s. d., p.101)

Jules Michelet (1798-1874), historiador de origem humilde - seu pai era trabalhador gráfico -, dirige a Edgard Quinet uma carta-dedicatória que serve de prefácio a Le peuple (1846). 
Narrando a própria infância, revela como escapou ao destino mais comum das crianças de sua origem - o trabalho precoce - e como os privilégios de que desfrutava lhe eram penosos. Durante o inverno, a 12 de fevereiro de 1845 , reflete: "Sentes calor; os outros, frio... isso não é justo... Oh! quem me consolará da dura desigualdade?". Conclui, dizendo consigo mesmo: "Se trabalhasses com o povo, não trabalharias para ele... Vai, pois, se dás à pátria a sua história, eu te absolverei de seres feliz" (Michelet, 1965, p.68). ${ }^{2}$ Mais adiante: "As provações da infância estão sempre presentes no meu espírito: conservei a impressão do trabalho, da vida áspera e laboriosa, continuei povo" (p.70).

"Quase sempre, os que sobem, perdem com isso, porque se transformam: tornam-se mistos, bastardos: perdem a originalidade de sua classe, sem ganhar a de uma outra. O difícil não é subir, mas, subindo, continuar o mesmo" (p.70). É também do mesmo prefácio a observação: “O homem constrói sua alma sobre a própria situação material: coisa estranha! há alma de pobre, alma de rico, alma de mercador... Parece que o homem não passa de acessório da fortuna" (p.183). Os autores de $A$ ideologia alemã poderiam subscrever a frase.

Finalmente, esse questionamento da condição adquirida e do direito de exercer a atividade de professor e de escritor resolve-se na observação justa, assim formulada: "Falo, porque ninguém falaria em meu lugar" (p.72). ${ }^{3}$

Além de, a seu modo, manifestar preocupação semelhante, Graciliano Ramos tem exigências bem claras quanto à sua atividade específica, isto é, quanto à estética do romance. Em fevereiro de 1935, comenta a declaração de Jorge Amado, segundo a qual "o romance vai suprimir o personagem, matar o indivíduo. O que interessa é o grupo - uma cidade inteira, um colégio, uma fábrica, um engenho de açúcar". A essa concepção, contrapõe: "Se isso fosse verdade, os romancistas ficariam em grande atrapalhação. Toda a análise introspectiva desapareceria. A obra ganharia em superfície, perderia em profundidade" (Ramos, 1967, p.96).

Habilmente, mostra que, apesar da teoria proclamada, crítica ingênua a uma concepção de história como fruto da ação do herói individual, os melhores momentos de Suor são justamente aqueles em que o escritor desmente na prática o próprio programa.

Dois anos e meio depois, julho de 1937, comentando Porão, de Newton Freitas, reportagem a respeito da experiência carcerária na Colônia Correcional de Dois Rios, observa: "O autor só nos mostra a parte externa dos indivíduos. As suas personagens andam bem, falam, mexem-se. Notamos os seus movimentos e vemos onde elas pisam, mas não percebemos o interior delas. Estão atordoadas, evidentemente, não podem pensar direito, mas teria sido bom que os acontecimentos se apresentassem refletidos naqueles espíritos torturados". Depois de assinalar que a narração se limita a uma "visão puramente objetiva", pondera: "Talvez isto se explique por ele ter querido ser honesto demais. Como as suas personagens são reais, é possível que tenha receado enganar-se olhando-as por dentro" (Ramos, 1967, p.100-1). 
Numa entrevista de 1944, declara:

Acho que não é o tema que tem a maior importância. A miséria, por exemplo, pode não dar a quem a trata a mesma impressão que naquele que a sofre [...]. Objetivamente ela pode ter sido [tratada]. O objeto, a coisa, não está ali dentro do livro? Justamente o que desafinou foi a parte subjetiva. E sem ela não pode haver obra nenhuma, porque qualquer um só pode escrever o que sente e não o que os outros estão sentindo ou poderiam sentir. ${ }^{4}$

Finalmente, numa carta de $1^{\circ}$ set. 1946, a Haroldo Bruno, explicita o vínculo entre técnica literária e intenção política:

no começo apenas desejei mostrar uma cidadezinha do interior - fuxicos, preguiça, conversas à porta da farmácia. Até [que] por volta de 1930 surgiram ataques à novela de costumes, ao estudo social, ao documento e elogios imoderados ao romance introspectivo. Sem dúvida pretendiam anular o fator econômico - e em conseqüência apresentaram-nos fantasmas. Ora, essas divagações arbitrárias não me despertavam interesse. Achei que só realizaríamos introspecção direita examinando a coisa externa, pois o mundo subjetivo não elimina o objetivo: baseia-se nele. Quem fugia à observação tinha evidentemente um fim político, mas as mofinas contra as reportagens eram de fato razoáveis. Conseguiríamos, evitando a parolagem chinfrim dos comícios, ferir os nossos inimigos com as suas próprias armas. Usaríamos até a linguagem correta, instrumento que eles de ordinário não utilizam. A sintaxe é também uma arma, não lhe parece? É meio de opressão. Assim pensando, fiz os meus últimos livros. (apud Bruno, 1957, p.97-9, nota)

\section{Viver com}

A prisão foi uma experiência fundamental na vida adulta de Graciliano Ramos. Ao lado de Infância, pode-se dizer que Memórias do cárcere, narrativa de dez meses de cadeia, fornece, mais que uma autobiografia, mais que um documento histórico, uma chave de compreensão da produção literária daquele escritor. $^{5}$

Escrito lentamente - as primeiras notas abandonadas são de 1937 - até o final da vida, em 1953, o livro mistura a narrativa do quotidiano imediato da prisão com reflexões retrospectivas sobre sua atividade literária. São particularmente ricas as observações a propósito das fontes biográficas de Angústia.

É preciso tentar esclarecer por meio de que mediações atuou aquela vivência, que ele afirma decisiva para a empresa de falar do sertanejo pobre, em Vidas secas. ${ }^{6}$

Numa crônica de 1937, recorda a "lição de coisas" que a polícia política involuntariamente ofereceu aos intelectuais, em 1936:

Mostraram sem nenhuma cerimônia: o tratamento que dispensam aos malandros e aos vagabundos foi apresentado sem disfarce aos intelectuais, que durante um ano se confundiram com vagabundos e malandros, numa promiscuidade nunca vista por essas bandas.

Foi excelente, e todos devem estar satisfeitos. Sem essa aproximação, não conheceríamos nunca a verdadeira desgraça. 
Andamos muito tempo fora da realidade, copiando coisas de outras terras. Felizmente nestes últimos anos começamos a abrir os olhos, mas certos aspectos da vida ficariam ignorados se a polícia não nos oferecesse inesperadamente o material mais precioso que poderíamos ambicionar. (Ramos, 1967, p.100)

Mas não foi só matéria-prima o que a experiência do cárcere forneceu a nosso romancista: ajudou a retificar, confirmando e tornando concretas, isto é, experimentadas na pele, concepções até então abstratas.

Além dos "vagabundos e malandros", os intelectuais puderam conhecer também trabalhadores que eram militantes políticos e conviver com eles. $\mathrm{O}$ estivador Desidério, "mulato ríspido, estrábico, bilioso" incomoda por seus modos sumários: “exibiu sem disfarce ódio seguro aos burgueses, graúdos e miúdos. Todos nós que usávamos gravata, fôssemos embora uns pobres diabos, éramos para ele inimigos". Mais chocante, no entanto, será a franqueza rude com que ele aprecia uma proposta infeliz apresentada por Graciliano numa reunião do Coletivo que se organizara no Pavilhão dos Primários: "Besteira”. A cólera e o espanto do escritor cedem à reflexão, a teoria encontrava pela primeira vez um apoio na realidade palpável, audível, visível, na realidade prática: a ideia, diz ele, se materializava. A citação, embora longa, justifica-se pela riqueza de matizes, que se perderia em resumo:

As duas proposições finais obtiveram recusa unânime. Essa deplorável estréia varreu-me certas nuvens importunas: sempre me excedera em afirmações categóricas, mais ou menos vãs; achava agora uma base para elas. Evidentemente as pessoas não diferiam por se arrumarem numa ou noutra classe; a posição é que lhes dava aparência de inferioridade ou superioridade. Evidentemente. Mas evidentemente por que? A observação me dizia o contrário. Homem das brenhas, afeito a ver caboclos sujos, famintos, humildes, quase bichos, era arrastado involuntariamente a supor uma diversidade essencial entre eles e os patrões. O fato material se opunha à idéia - e isto me descontentava. Uma exceção rara, aqui, ali, quebrava a monotonia desgraçada: o enxadeiro largava o eito, arranjava empréstimo, economizava indecente, curtia fome, embrenhava-se em furtos legais, chegava a proprietário e adquiria o pensamento e os modos do explorador; a miserável trouxa humana, batida a facão e a vergalho de boi, resistente ao governo, à seca, ao vilipêndio, resolvia tomar vergonha, amarrar a cartucheira à cinta, sair roubando, incendiando, matando como besta-fera. Essas discrepâncias facilmente se diluíam no marasmo: era como se os dois ladrões, o aceito e o réprobo, houvessem trazido ao mundo a condição inelutável: pequenas saliências no povo imóvel, taciturno, resignado. Naquele instante a aspereza do estivador me confirmava o juízo. Lá fora sem dificuldade me reconheceria num degrau acima dele; sentado na cama estreita, rabiscando a lápis um pedaço de papel, cochichando normas, reduzia-me, despojava-me das vantagens, acidentais e externas. De nada me serviam molambos de conhecimentos apanhados nos livros, talvez até isso me impossibilitasse reparar na coisa próxima, visível e palpável. A voz acre me ofendera os ouvidos, arrancara-me exclamações de espanto, abafadas nas preocupações do Coletivo: ninguém ali estava disposto a lisonjear-me. Aceitei o revés como quem bebe um remédio amargo. Afinal a minha opinião se confirmava. (Ramos, 1953-1954, v.II, cap.8, p. 62, 66-7) 
É uma lição de humildade, inesquecível, que impõe uma exigência ao escritor e, por ricochete, aos seus leitores de então e de hoje: é preciso abrir os olhos, desconfiar das aparências; mas é preciso também perceber o que as aparências podem revelar, contra as ideias recebidas e contra os "molambos de conhecimentos apanhados nos livros". Saber distinguir, em suma, o que é essencial e interno, daquilo que é acidental e externo. A fórmula é simples, mas nada é mais difícil na prática. $\mathrm{O}$ zelo de distinguir, em Graciliano Ramos, tem caráter sobretudo político e ideológico. Com outra ênfase, filosófica ou metafísica, Riobaldo expõe perplexidades semelhantes:

Que isso foi o que sempre me invocou, o senhor sabe: eu careço de que o bom seja bom e o rúim ruím, que dum lado esteja o prêto e do outro o branco, que o feio fique bem apartado do bonito e a alegria longe da tristeza! Quero todos os pastos demarcados... Como é que posso com êste mundo? A vida é ingrata no macio de si: mas transtraz a esperança mesmo do meio do fel do desespêro. Ao que, êste mundo é muito misturado.

Ou, mais adiante: "A fantasia, minha agora, nesta conversa - o senhor me atalhe. Se não, o senhor me diga: prêto é prêto? branco é branco? Ou: quando é que a velhice começa, surgindo de dentro da mocidade" (Rosa, 1967, p.169 e 188). ${ }^{7}$

Não nos enganemos, porém: o convívio, com tudo que ele implica, a partilha do pão, da esteira de dormir, do sofrimento comum, do destino comum, fabrica companheiros, camaradas, mas não dissolve as diferenças. Graciliano estava bem ciente: por isso Vidas secas é narrado em terceira pessoa.

\section{Do conto ao romance}

Quando escreveu o conto "Baleia", Graciliano Ramos apontou, numa carta à sua mulher, $\mathrm{D}$. Heloísa Ramos, dificuldades que enfrentou na tarefa e explicitou algumas intenções:

Escrevi um conto sobre a morte duma cachorra, um troço difícil como você vê: procurei adivinhar o que se passa na alma duma cachorra. Será que há mesmo alma em cachorro? Não me importo. $\mathrm{O}$ meu bicho morre desejando acordar num mundo cheio de preás. Exatamente o que todos nós desejamos. A diferença é que eu quero que eles apareçam antes do sono, e padre Zé Leite pretende que eles nos venham em sonhos, mas no fundo todos somos como a minha cachorra Baleia e esperamos preás. É a quarta história feita aqui na pensão. Nenhuma delas tem movimento, há indivíduos parados. Tento saber o que eles têm por dentro. Quando se trata de bípedes, nem por isso, embora certos bípedes sejam ocos; mas estudar o interior duma cachorra é realmente uma dificuldade quase tão grande como sondar o espírito dum literato alagoano. Referindo-me a animais de dois pés, jogo com as mãos deles, com os ouvidos, com os olhos. Agora é diferente. $\mathrm{O}$ mundo exterior revela-se a minha Baleia por intermédio do olfato, e eu sou um bicho de péssimo faro. (Ramos, 1980, p.194-5)

É provável que o autor do conto não alcançasse com precisão, naquela altura, o modo como seriam armados seus antecedentes, no futuro romance, e 
quais os desdobramentos e implicações contidos no primeiro núcleo dramático. Do mesmo modo nós, leitores lineares de Vidas secas, não sabemos desde o primeiro capítulo que a cachorra, ali presente, é "aquela que deve morrer" no nono conto-capítulo do livro.

O romance foi composto e publicado parceladamente, assim como, sabemos hoje, tudo quanto Graciliano Ramos produziu, depois de 1937. Os volumes que se chamariam Vidas secas (1938), A terra dos meninos pelados (1940), Histórias de Alexandre (1944), Infância (1945), Insônia (1947), Memórias do cárcere (1953), chegaram ao público à medida que foram redigidas, sob forma de narrativas autônomas, por via de jornal ou revista (cf. Lima; Reis, 1992).

Não se deve concluir, no entanto, que a obra é um aglomerado arbitrário de contos. Pode perceber-se um arranjo intencional e até simétrico dos capítulos: em número de treze, os das extremidades narram duas secas; o sétimo, em posição central, não por acaso, chama-se "Inverno". Há mesmo quem sustente que a simetria é completa; o romance giraria em torno de um eixo, em que, dois a dois, equidistantes, os capítulos conservariam uma afinidade temática; se quisermos imaginar em vez de eixo, um centro, teríamos sete círculos concêntricos. $^{8}$

A economia e articulação, porém, não exige, nem de fato apresenta, simetria tão perfeita. Tendo a crer que "Inverno" e "Festa", sétimo e oitavo capítulos, no miolo da obra, encerram os momentos de menor tensão dramática da narrativa. Podemos então agrupar os demais capítulos por afinidade temática e em relativa simetria: "Mudança", o primeiro capítulo, articula-se com "Fuga", o último; "Fabiano", o segundo, com "O mundo coberto de penas", penúltimo; "Cadeia", o terceiro com o antepenúltimo, "O soldado amarelo"; o quarto, "Sinha Vitória", liga-se a "Contas", décimo, e, por fim, os capítulos "O menino mais novo" e "O menino mais velho", quinto e sexto articulam-se com "Baleia", o nono.

\section{Coisas de não}

A partir de uma situação de carência extrema, o romance movimenta uma família sertaneja, tangida pela seca - Fabiano, sinha Vitória, ${ }^{9}$ o menino mais novo, o menino mais velho e a cachorra Baleia. Famintos e sedentos, transportam exíguos pertences, em "Mudança"; acompanha-se as vicissitudes desse grupo de viventes durante um instável período sedentário, até novo êxodo, em "Fuga".

Em carta a João Condé, junho de 1944, declara:

Fiz o livrinho sem paisagens, sem diálogos. E sem amor. Nisso, pelo menos, ele teve alguma originalidade. Ausência de tabaréus bem falantes, queimadas, cheias e poentes vermelhos, namoros de caboclos. A minha gente, quase muda, vive numa casa velha de fazenda. As pessoas adultas, preocupadas com o estômago, não têm tempo de abraçar-se. Até a cachorra é uma criatura decente, porque na vizinhança não existem galãs caninos. (apud Ramos, 1987, p.129) 
Aparentemente modesto, limita-se a reivindicar para seu "livrinho" "alguma originalidade". A insistência nas negativas, manifesta nas palavras "sem" (três vezes repetida), "ausência", "não" (repetida duas vezes), oculta três polêmicas: contra certa tradição de retórica inflada na literatura brasileira, contra aquele regionalismo de exterioridade, de paisagem, e contra a maneira convencional de expor a voz das camadas populares, simpática mas estereotipada. Exibe-se aí um exercício atento de leitura, que resulta em exclusão e escolha; a ênfase nas negações encobre, no entanto, a busca positiva de outra tradição narrativa, mais sóbria e enxuta.

A retórica está a serviço da intenção expressiva: o romance trabalhará o tecido das necessidades e das carências. "As pessoas adultas, preocupadas com o estômago, não têm tempo de abraçar-se". A hierarquia entre "fome" e "amor" - "estômago" e "abraço", na frase de Graciliano Ramos -, bem possivelmente, oculta outra polêmica, de modo que convém retomar adiante essa dicotomia.

\section{Os simples}

O episódio de Baleia inscreve-se nessa mesma lógica de trabalhar com os mínimos e os ínfimos, "coisas de não: / fome, sede, privação"; "coisas de não, / ocas, leves" (Melo Neto, 1975, p.210-11). A escolha da personagem, um animal, uma cachorra, e da situação dramática, a morte, tangencia os extremos limites da simplicidade e da aniquilação. Michelet (1965, p.199) sugere, em Le peuple, uma espécie de hierarquia dos simples: abaixo das camadas populares, viriam as crianças e, por fim, os animais:

Por mais apressado que esteja, neste exame dos simples, dos humildes filhos do instinto, o coração me detém e me obriga a dizer uma palavra a respeito dos simples por excelência, dos mais inocentes, dos mais infelizes talvez, quero dizer, dos animais.

As primeiras três páginas do capítulo narram a recente doença da cadela, aparentemente hidrófoba e as tentativas de cura (Fabiano "amarrara-lhe no pescoço um rosário de sabugos de milho queimados" (p.103) ${ }^{10}$ ); lembram-lhe o comportamento solidário, quase humano; relatam a difícil decisão de Fabiano de sacrificar o animal doente, e a resistência que todos tentam opor a ela.

O caso é que, no grupo dos "simples" que se move em Vidas secas, não é tão marcada a distinção, a hierarquia entre seus membros, sobretudo entre a cadela e as crianças: "Ela [Baleia] era como uma pessoa da família: brincavam juntos os três, para bem dizer não se diferençavam, rebolavam na areia do rio e no estrume fofo que ia subindo, ameaçava cobrir o chiqueiro das cabras" (Ramos, 1953a, p.103-4). ${ }^{11}$ Como as crianças, ela recebe as descargas do mau humor de Fabiano e de Sinha Vitória, em forma de pontapés (p.48, 70, 71). A narrativa da execução é sóbria e comovente:

Ao chegar às catingueiras, [Fabiano] modificou a pontaria e puxou o gatilho. A carga alcançou os quartos traseiros e inutilizou uma perna de Baleia, que se pôs a latir desesperadamente. 
Ouvindo o tiro e os latidos, sinha Vitória pegou-se à Virgem Maria e os meninos rolaram na cama chorando alto. Fabiano recolheu-se. (p.105)

As quatro páginas finais narram a agonia e a morte de Baleia. É possível distinguir com bastante clareza três camadas de linguagem: a primeira é a que registra a "visão puramente objetiva" - os movimentos da cachorra, vistos externamente; a segunda, a dos acontecimentos "refletidos naquele espírito torturado"; a terceira, a que exprime o ponto de vista, acompanha com distância crítica aquele reflexo interno. É um procedimento que, guardadas as diferenças, o narrador conserva no romance inteiro, para todas as demais personagens.

Vejamos mais de perto como opera essa técnica: os seis primeiros parágrafos dessa segunda parte narram a progressiva perda dos movimentos, até a imobilidade completa do animal, cosido à terra: de humus deriva o adjetivo bumilis, bumilde. Ao mesmo tempo, ficamos conhecendo o medo, a lembrança de prazeres passados, que passam pelo espírito de Baleia, lembrança que parece inoportuna, inadequada, por misturar-se sem contraste com a desgraça presente. A justaposição daquela lembrança e essa realidade, contudo, é a marca, discreta e implícita, da distância do narrador. Essa distância pode alargar-se e explicitar-se:

Uma sede horrível queimava-lhe a garganta. Procurou ver as pernas e não as distinguiu: um nevoeiro impedia-lhe a visão. Pôs-se a latir e desejou morder Fabiano. Realmente não latia: uivava baixinho, e os uivos iam diminuindo, tornavam-se quase imperceptíveis. (p.105-6)

A frase inicial, referindo sede e garganta queimando, parece um registro objetivo e até banal, mas não é: o narrador não fala de sinais externos e perceptíveis, mas de sensações internas do animal. A segunda, adivinha a intenção da cachorra, "procurou ver as pernas"; depois, registra-lhe a percepção bloqueada, "não as distinguiu"; por fim, chega aos limites da consciência canina, atribuindo, solidário com ela, a visão embaçada a um nevoeiro. Observe-se que o narrador se vale de uma metáfora corrente para designar a vista turva. Aqui, no entanto, é preciso admitir uma tensão entre o sentido literal e o metafórico: consciência animal não metafórica, que resulta em metáfora, quando transposta em linguagem humana. Baleia não hesita: o nevoeiro e, depois, a noite, estão fora dela.

"Pôs-se a latir e desejou morder Fabiano": os dois membros desse período coordenado expressam a subjetividade de Baleia, apesar da aparência de registro objetivo do primeiro. Isso se esclarece na frase seguinte, onde a posição distanciada do narrador marca-se, com nitidez, no advérbio "realmente": entre a percepção ou o desejo subjetivos de Baleia, de "latir", e a realidade, "uivava baixinho", percebida pela consciência externa, do narrador, cava-se um intervalo. "Uivava baixinho" é o único registro de atitude exteriorizada, nesse trecho.

A narrativa acompanha o sucessivo desaparecimento da vista, do olfato, do paladar, da audição e do tato de Baleia, nessa ordem. Ela conserva, no entanto, até o fim, fiapos de "memória": medo, impossibilidade de revolta, peso dos deveres aprendidos, compensações do convívio humano. 
No último parágrafo, depois dessa perda dos sentidos, acompanhamos o mergulho do bichinho no sono da morte, precedido de um devaneio esperançoso: mais uma vez, se marca o contraste entre fantasia subjetiva e realidade, registrada pelo narrador.

Terá ficado claro, espero, que o ponto de vista equilibra-se tenso entre identificação e distanciamento. $\mathrm{O}$ distanciamento, no entanto, não suprime a afetividade (Bosi, 1988). ${ }^{12}$ Nesse capítulo, aliás, ela se manifesta com discrição, e delicadeza quase franciscana: refiro-me aos diminutivos aplicados à cachorra que, distribuídos ao longo do capítulo, poderiam tornar-se quase invisíveis: "coitadinha" (p.104), "criaturinha" e "cabecinha" (p.109).

\section{Entre lobo e cão}

Baleia é um animal de companhia e de trabalho. No início do primeiro capítulo do livro, vêmo-la ao lado do menino mais velho, proximidade voluntária, que antecipa a preferência e a afinidade mais tarde confirmadas. É assim que, quando Fabiano passa a carregar o menino desmaiado: "Ausente do companheiro, a cachorra Baleia tomou a frente do grupo. Arqueada, as costelas à mostra, corria ofegando, a língua fora da boca. E de quando em quando se detinha, esperando as pessoas, que se retardavam" (p.11).

Em "O menino mais velho", este, castigado por sinha Vitória, vai sentar-se longe de casa, acompanhado de Baleia: "Todos o abandonavam, a cadelinha era o único vivente que lhe mostrava simpatia" (p.69). A palavra "simpatia" carrega aqui seu sentido etimológico mais forte, de sentir ou sofrer junto, o que é uma forma particular, afetiva, do sentimento de solidariedade.

A solidariedade talvez seja o valor essencial dessa comunidade de viventes, consciente ou não. Por solidariedade, Baleia deixa de devorar sozinha o preá que havia caçado, repartindo-o com os retirantes (p.14); é o mesmo sentimento que impede Fabiano de entrar no cangaço, saída individual, revolta sem consequências. "Cadeia" termina com a conquista ainda nebulosa da consciência de Fabiano: poderia entrar num bando de cangaceiros e matar, não o soldado amarelo, um infeliz, pau mandado, mas os "donos dele": "Mas havia a mulher, havia os meninos, havia a cachorrinha" (p.43).

Acima do desejo de vingança, vem a solidariedade que abraça família e cachorrinha. É uma limitação, mas também instintiva sabedoria de perceber que não pode haver saída individual contra a opressão. Vista de outro ângulo, a solidariedade confina com a simbiose. O menino mais velho tem um lampejo de percepção disso, quando recenseia seu conhecimento do mundo:

Além havia uma serra distante e azulada, um monte que a cachorra visitava, caçando preás, veredas quase imperceptíveis na catinga, moitas e capões de mato, impenetráveis bancos de macambira - e aí fervilhava uma população de pedras vivas e plantas que procediam como gente. Esses mundos viviam em paz, às vezes desapareciam as fronteiras, habitantes dos dois lados entendiam-se perfeitamente e auxiliavam-se. (p.69-70) 
Vida e solidariedade: simbiose. Importante notar que, desde o título, temos a palavra "vida", significativamente no plural. $\mathrm{O}$ adjetivo "secas" torna esse um dos títulos mais prolixos de Graciliano Ramos: vidas, no entanto secas; secas, no entanto vidas. ${ }^{13}$ Os três mundos, mineral, vegetal e animal, compõem um conjunto único, solidário ecúmeno, casa (oikós) que é de todos. De todos os "viventes", outra palavra reveladora: a forma participial, verbal ou deverbal do substantivo, veicula um componente dinâmico: viver é, antes de tudo, atividade, trabalho.

Ficou dito que Baleia é também um animal de trabalho: é ela que conduz as cabras ao bebedouro; preocupa-se com os animais soltos na noite particular de sua agonia, povoada de suçuaranas (p.108); foi amestrada para farejar a criação que se extravia, ao comando do vaqueiro Fabiano:

[Fabiano] Bateu palmas:

- Ecô! ecô!

- A cachorra Baleia saiu correndo entre os alastrados e quipás, farejando a novilha raposa. Depois de alguns minutos voltou desanimada, triste, o rabo murcho. Fabiano consolou-a, afagou-a. Queria apenas dar um ensinamento aos meninos. Era bom eles saberem que deviam proceder assim. (p.24-5)

Homem e bicho confinam: a comunicação entre Fabiano e Baleia estabelece-se mediante palmas e aboio, vocalização que não chega a ser linguagem plenamente articulada. Essa voz, no entanto, é eficiente como instrumento de trabalho: vale como linguagem. A limitação cultural e linguística do vaqueiro dá a medida do que se requer dele: trabalho mecânico e submissão. Nessa passagem e ao longo do capítulo inteiro, ressurge um complexo problema recorrente em toda a obra de Graciliano Ramos: o da educação. Com frequência, cruzam-se, em sua obra, as ideias de educação e domesticação. Sejam três exemplos. O primeiro, de Caetés, uma fala de Miranda Nazaré a Evaristo Barroca:

[...] Quando o nosso matuto tem um filho opilado ou raquítico, manda domesticá-lo a palmatória e a murro. $\mathrm{O}$ animal aprende cartilha e fica sendo consultor lá no sítio, torna-se mandrião, fala difícil, lê o Lunário Perpétuo e o Carlos Magno, à noite, na esteira, para a família reunida em torno da candeia. Qual é o resultado? A primeira garatuja que o malandro tenta é uma carta falsa em nome do pai, pedindo dinheiro ao proprietário. (Ramos, 1953, p.90-1)

A afirmação não parece metafórica: Miranda pretende, ao contrário, designar as coisas pelo nome correto. $\mathrm{Na}$ opinião dele, erraria quem acreditasse que a escola, naquelas condições, fornecesse mais que adestramento. No capítulo 9, do primeiro volume de Memórias do cárcere, topamos uma variante: “[...] as populações da roça distanciavam-se enormemente do litoral e animalizavam-se na obediência ao coronel e a seu vigário, as duas autoridades incontrastáveis" (Ramos, 1953a, v.I, p.71).

"Animalizavam-se na obediência" diz a mesma coisa, com outra formulação. Terceiro exemplo, explícito, pode encontrar-se numa crônica, "Habita- 
ção", publicada na revista Cultura política, em agosto de 1941, posteriormente reproduzida em Viventes das Alagoas: "Uma habitação horrível, como vêem. Contudo viveu ali, sem se queixar, uma família decente, religiosa e pastoril, domesticada no regime patriarcal" (Ramos, s. d., p.45).

A escolha desses termos não deve ser encarada como casual: expressam ponto de vista sedimentado acerca do problema. A educação popular, sustenta com razão, não se propõe a favorecer o desenvolvimento intelectual das pessoas, mas a inculcar novos hábitos, com vistas apenas a desenvolver aptidão para os serviços requeridos delas. ${ }^{14}$ Exatamente como na domesticação, uma vez conseguidos esses efeitos mínimos, até mediante castigo, se se julgar necessário, o processo é intencionalmente interrompido. A influência da domesticação no psiquismo do animal, explica um estudioso, compreende duas fases:

Durante a primeira [fase], o Homem coloca os animais nas novas condições e solicita deles, conscientemente ou não, reações inteligentes, diversas das reações instintivas. Depois, tendo escolhido as que lhe são úteis, fixa-as graças ao treinamento, eliminando assim a inteligência que se tornou inútil e até mesmo nociva, em razão dos gestos parasitários que ela determina. (Dechambre, 1971, p.80)

Aplicada, no romance, para definir a condição do vaqueiro, "bruto" é outra palavra que expressa bem essa fusão homem-bicho. Sua "brutalidade" (p.41) interessa a seus patrões, pois uma verdadeira educação seria, no limite, libertadora. Os exemplos ao alcance de Fabiano, no entanto, não lhe permitem avaliação clara: intui o poder da instrução, quando pensa no saber livresco de seu Tomás da bolandeira. Mas esse fornece também o contra-argumento, uma vez que, diante da desgraça da seca, resta indefeso. Percebe, ao mesmo tempo, que, mesmo com menos ciência, tem mais poder o patrão, proprietário da terra, do gado, dos instrumentos de trabalho. Não importa que esteja correta a aritmética de sinha Vitória, no momento do acerto de contas: ao dono da terra pertence arbitrar sobre o certo e o errado. Ao vaqueiro resta o recurso de tirar força da fraqueza, declarando-a abertamente, como faz diante do patrão ("Era bruto, não fora ensinado", p.114), ou diante do fiscal da prefeitura, que lhe quer cobrar imposto pela venda de carne de porco ("não compreendia nada, era bruto", p.116). Pascal afirma que "todas as fraquezas muito aparentes são forças" (Pascal, Pensées, f.578, apud Jankélévitch, 1987, p.87). O contrário também pode ser verdade: no desfecho do episódio do soldado amarelo, a atitude de suposta subserviência é a mais sábia: chama-se contenção. A força de Fabiano consiste em dominar o primeiro impulso, instintivo e apaixonado, que incitava a uma vingança de curto alcance. Trata-se de resposta de homem consciente e não de animal domesticado. Nunca é simples definir a fronteira entre fraqueza e força. "Inutilizar-se por causa de uma fraqueza fardada que vadiava na feira e insultava os pobres! Não se inutilizava, não valia a pena inutilizar-se. Guardava a sua força.” (p.129). 
A interação homem-animal ou mais amplamente homem-natureza pode ser significativa, uma vez que se entrelaça com as relações que os homens mantêm entre si. ${ }^{15}$ Assim, quando se examina o lugar que Baleia ocupa na família de Fabiano, pode-se compreender a contraditória condição do homem pobre, naquele contexto. Com efeito, ele vive constrangido pela natureza e pela sociedade, mas, nos limites acanhados a que a necessidade o encantoa, pelo menos no seu espaço doméstico, procura construir seu ideal de convivência. Difícil, para ele, discernir, no patrimônio da tradição, o que pode ou deve ser conservado. Mas não se trata de um problema teórico, abstrato. "A fome também é professora", diz Carolina Maria de Jesus.

Naquele universo já criado, no princípio era a vida, isto é, os viventes. É por isso, talvez, que parecem tão terríveis os sacrifícios, primeiro, o do papagaio, ${ }^{16}$ depois o de Baleia. Em contrapartida, é esclarecedor o modo como ela desempenha os papéis de animal de companhia e de trabalho: é a sua escola de solidariedade e de cooperação, essenciais na conservação da vida.

É certo que, naquelas condições e ainda nas atuais, "O trabalho é a melhor e a pior das coisas" conforme escreve Alain (1949, p.146), "a melhor, se é livre; a pior, se é servil". Mas é lícito esperar que, num mundo futuro, construído pelo trabalhador para todos os homens, o trabalho possa livrar-se dessa marca de servidão.

A Baleia cabe, entre outras tarefas, conduzir as cabras ao bebedouro e vigiá-las para que não se desgarrem, expondo-se às suçuaranas, como ficou dito. Edmond Dechambre (1971, p.45) explica que o "sentimento da relação entre os seres e as coisas [...] está na origem da noção de propriedade". Esse seria, segundo ele, o ponto de partida para desenvolver-se no cão uma de suas mais antigas funções, a de sentinela. Baleia zela pela vida dos animais de criação e pela vida das crianças. Diferente dela é Tubarão, guarda da propriedade de Paulo Honório, em S. Bernardo. Compatível com seu papel de capanga é o nome ameaçador que o dono lhe atribui (Ramos, 1953c, p.35). Recorde-se um poema, "Na tenda do operário", do hoje desconhecido Mariano de Oliveira, assim resumido por Machado de Assis (1986, p.827):

O poeta ia passando e viu aberta uma porta, uma casa de operário; era de noite, A noite, a sombra funda, o ermo grande e mudo;

Tudo dentro era negro e negro em torno tudo;

pareceu-lhe que lá dentro da casa houvera algum atentado, e então sentou-se à porta, à espera que voltasse o dono. $\mathrm{O}$ dono volta; é um operário, o poeta adverte-o do descuido que cometera: ao que o operário responde que ninguém lhe iria roubar o que não tem. O poeta despede-se, segue, pára a distância, e parece-lhe então que efetivamente se detivera sem necessidade, porque ali velava uma sentinela firme:

\section{O anjo da miséria a vigiar a porta.}




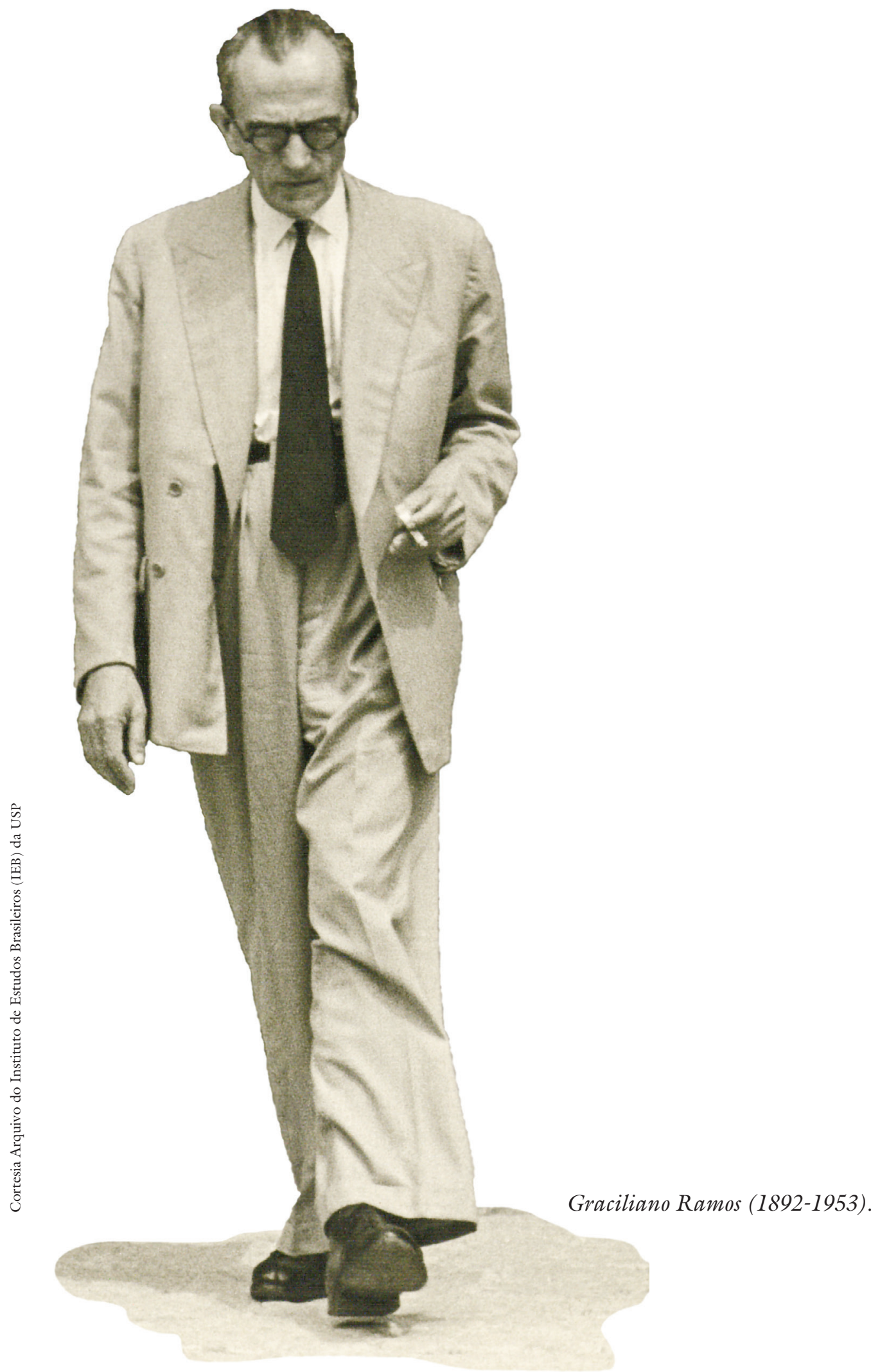




\section{De te fabula narratur}

Em confronto com a sociedade mais ampla, para compreender a própria condição, Fabiano compara-se a um cachorro: "Era um desgraçado, era como um cachorro, só recebia ossos. Por que seria que os homens ricos ainda the tomavam uma parte dos ossos?" (p.177).

A rigor uma situação inferior à do cão. Pierre-Pascal Furth (1976, p.94), num ensaio sobre Jack London, informa que, no inglês norte-americano, "underdog designa o proletário e o homem explorado". Estamos bem distantes do ambiente solidário da família. Na sociedade inclusiva vigora a regra da exploração, que reduz o trabalhador ao animal amestrado ("gorila domesticado", conforme queria Taylor (Gramsci, 1978, p.375-413)). Essa redução se traduz seja pela síntese metafórica da língua inglesa, o "sub-cão", seja pela comparação e seu desenvolvimento, sugeridos pelo vaqueiro. $\mathrm{O}$ cão fornece o espelho em que o trabalhador enxerga o próprio rosto.

Também por isso o sacrifício de Baleia desnorteia a família, mais que o do papagaio. Sinha Vitória admite que "a decisão de Fabiano era necessária e justa". Num momento de raiva, chega a injuriar mentalmente a cachorra: "Bicho nojento, babão" e considera "Inconveniência deixar cachorro doido solto em casa" (p.104). Mas logo pressente a extraordinária responsabilidade daquela decisão e se questiona: "achava difícil Baleia endoidecer", ao mesmo tempo que "lamentava que o marido não houvesse esperado mais um dia para ver se realmente a execução era indispensável” (p.104-5). A morte, de fato, é irrevogável e nenhuma certeza parece suficientemente sólida para justificá-la, muito menos uma presunção, ainda que bem fundada. A sombra dessa execução vai acompanhar todos os passos da família.

O julgamento capital, escreve Albert Camus, rompe a única solidariedade humana indiscutível, a solidariedade contra a morte, e só pode ser legitimado por uma verdade ou um princípio que se coloque acima dos homens. (Camus, 1957, p.169)

As pessoas visadas pelas imagens animalescas são excluídas da condição humana e, por conseguinte, da comunidade dos homens: a pena de morte fica, portanto, justificada. A metáfora origina-se muito provavelmente de uma tradição oriental, que considera o cão animal desprezível. No Apocalipse, entre os excluídos da nova Jerusalém, figuram em primeiro lugar os cães: "Fora os cães, os envenenadores, os impudicos, os homicidas, os idólatras, e todos aqueles que amam e praticam a mentira" (Apc, 22, 15).

A utilização do recurso, porém, pode ser irônica, funcionando como denúncia, o que me parece ser o caso de Graciliano Ramos. Entre os antecedentes, estão o "Colóquio dos cães", das Novelas exemplares (1613), de Cervantes, paródia das novelas picarescas, e uma passagem de Os caracteres (1688) de La Bruyère, relativa aos camponeses, que transcrevo: 
Vêem-se, dispersos pelo campo, certos animais ferozes, machos e fêmeas, pretos, lívidos e totalmente queimados pelo sol, presos à terra, que escavam e remexem com uma obstinação invencível; têm como que uma voz articulada, e quando se erguem sobre os seus pés, apresentam uma face humana, e com efeito são homens. Retiram-se à noite em covis, onde vivem de pão preto, água e raízes; poupam aos outros homens o trabalho de semear, lavrar e colher para viver, e merecem, portanto, que não lhes falte este pão que semearam. (La Bruyère apud Auerbach, 1971, p.321). ${ }^{17}$

Em 1934, Rubem Braga retoma La Bruyère, a propósito de um decreto do então presidente Getulio Vargas que declarava "todos os animais existentes no país [...] tutelados do Estado". Relata longamente "as barbaridades que sofrem os animais neste mundo", para concluir:

É interessante notar que, devido a certas semelhanças, algumas pessoas pensam que esses animais são também homens. É engano. Eles, de fato, têm alguma parecença com os homens; mas não são homens, são operários. (Braga, 1936, p.83-5)

"Cachorro doido", além da metáfora animalesca, acrescenta a do "louco", outro excluído da comunidade humana. Essa expressão ou alguma outra, sinônima, aplica-se correntemente para designar o transgressor, seja ele o criminoso comum, seja o criminoso político ou o opositor. O libelo de André Vichinski, acusador do estado soviético, no início dos processos de Moscou, termina assim: "Exijo que estes cães raivosos sejam todos fuzilados sem exceção". A 11 de março de 1938, proclama: “Todo o nosso país, jovens e velhos, espera e reclama uma só coisa: que os traidores e espiões que vendiam a nossa pátria ao inimigo sejam fuzilados como cães sarnosos" (Broué, 1966, p.52 e 15).

Exemplos de qualificações semelhantes podem ser encontradas sem dificuldade: em 1936, Édouard Herriot diz de Hitler: "Esse cão raivoso vai acabar soltando-se da corrente". Stálin fala de "feras fascistas". Hitler, por sua vez, em 1938 refere-se a Neville Chamberlain como "o cachorro mais ignóbil que ja tinha encontrado"; fala também de "cães bolchevistas" (Silveira; Moraes Neto, 1989 , p.45, 46, 254 e 304 ).

Atua aqui, talvez, aquela "razão de estado", a propósito da qual assim se pronuncia um cão do "Colóquio dos cães" de Cervantes: "cuando con ella se cumple, se ha de descumplir con otras razones muchas" (Saavedra, 1990, p.317).

\section{Tempos futuros}

"O importante é escrever duas páginas no condicional sem que ninguém perceba” (R. Ramos, 1987, p.13). Essa frase dita por Graciliano Ramos a seu filho, Ricardo, pode orientar com proveito a leitura de Vidas secas. Esse modo verbal rasga, no interior do registro banal e imediato das situações, a dimensão da perspectiva. Com efeito, o sentido básico do condicional é de abertura para o futuro. Tomemos como exemplo o parágrafo final de "Baleia":

Baleia queria dormir. Acordaria feliz, num mundo cheio de preás. E lamberia 


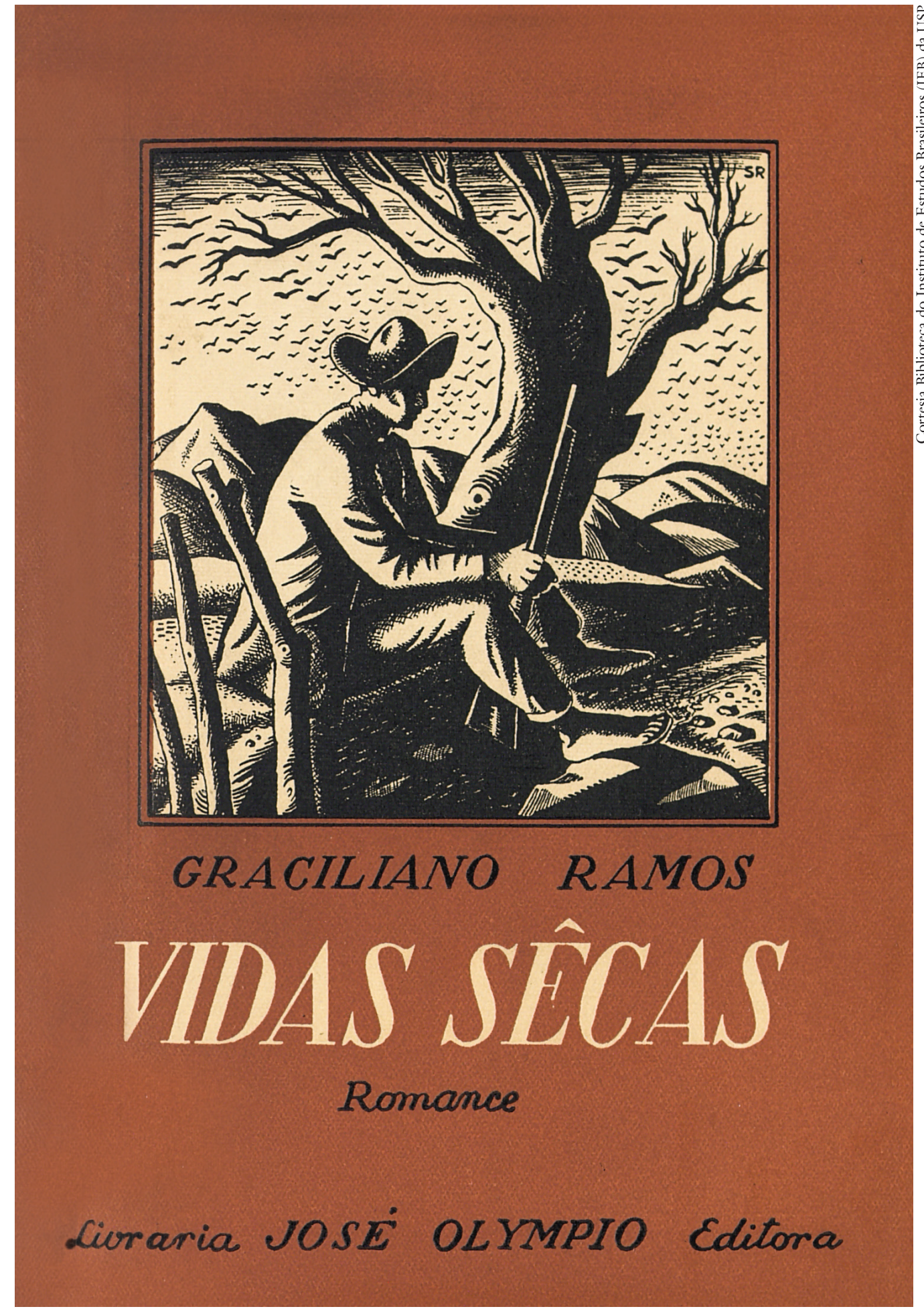

Capa da $1^{a}$ edição de Vidas secas (1938), de Graciliano Ramos, publicado por José Olympio. 
as mãos de Fabiano, um Fabiano enorme. As crianças se espojariam com ela, rolariam com ela num pátio enorme, num chiqueiro enorme. $\mathrm{O}$ mundo ficaria todo cheio de preás, gordos, enormes. (p.109)

O leitor e o narrador sabem que não haverá futuro para Baleia, que não se realizarão os sonhos de felicidade, de plenitude e de fartura: do sono da morte não se desperta. Do ponto de vista literal, estão elididas da frase uma antítese, que o contexto esclarece, e o enunciado da condição, “se...". Trata-se de uma hipótese irreal, fundada em condições inexequíveis, esperança vã.

Outras formas de condicional formulam-se em "Cadeia". Primeiro caso:

[...] sem aqueles cambões pesados [a família] não envergaria o espinhaço não, sairia dali como onça e faria uma asneira. Carregaria a espingarda e daria um tiro de pé de pau no soldado amarelo. Não. O soldado amarelo era um infeliz que nem merecia um tabefe com as costas da mão. Mataria os donos dele. Entraria num bando de cangaceiros e faria estrago nos homens que dirigiam o soldado amarelo. Não ficaria um para semente. (p.43)

Tampouco essas hipóteses se realizarão, mas o obstáculo não tem a mesma inelutabilidade: o impedimento deriva de uma opção consciente. Fica, no entanto, como possibilidade aberta: é o caminho de quem já não tem o que perder.

Segundo caso:

Os meninos eram uns brutos como o pai. Quando crescessem, guardariam as reses de um patrão invisível, seriam pisados, maltratados, machucados por um soldado amarelo. (p.44)

O condicional é precedido da oração temporal, introduzida por "quando": é a hipótese potencial. A experiência de gerações indicava o que se podia esperar, em condições "normais": "Tinha vindo ao mundo para amansar brabo, curar feridas com rezas, consertar cercas de inverno a verão. Era sina. O pai vivera assim, o avô também. E para trás não existia família” (p.117). Na cadeia, dificilmente poderia esperar outra coisa que não a provável continuidade do ciclo: o condicional, neste caso, veicula o desespero.

Sinha Vitória representa outra qualidade de esperança: ela não sonha, ela deseja:

Venderia as galinhas e a marrã, deixaria de comprar querosene. Inútil consultar Fabiano, que sempre se entusiasmava, arrumava projetos. Esfriava logo - e ela franzia a testa, espantada, certa de que o marido se satisfazia com a idéia de possuir uma cama. Sinha Vitória desejava uma cama real, de couro e sucupira, igual à de seu Tomás da bolandeira. (p.54)

A cama é uma aspiração bem próxima e bem concreta. No contexto, a cama conota também a ressurreição do desejo sexual de sinha Vitória:

Viera [...] um começo de prosperidade. Comiam, engordavam. Não possuíam nada: se se retirassem, levariam a roupa, a espingarda, o baú de folha e troços miúdos. Mas iam vivendo na graça de Deus, o patrão confiava neles - e eram quase felizes. Só faltava uma cama. Era o que aperreava sinha Vitória. (p.53) 
O desejo ressurge depois de satisfeitas as necessidades primordiais de alimentação. As grandes forças de preservação da vida são exatamente a fome e o amor, que garantem, uma, a conservação da existência individual; outro, a continuidade da espécie. Se fosse preciso, no entanto, definir anterioridade, é possível que a fome devesse prevalecer: "sine Baccho et Cerere friget Venus". ${ }^{18}$

A oposição entre o que se poderia chamar "idealismo" de Fabiano e o "realismo" de sinha Vitória manifesta-se também com evidência, por ocasião da festa a que vão na cidade: Fabiano embriaga-se e dorme, assaltado por pesadelos, enquanto sinha Vitória, aliviada da necessidade de urinar, instala-se o mais comodamente possível: "Ficou ali de cócoras, cachimbando, os olhos e os ouvidos muito abertos para não perder a festa" (p.97).

No capítulo final, novo momento crítico do romance, em que a família se retira quando ameaçados por mais uma seca, essas diferenças se reduzem. $\mathrm{O}$ casal se reaproxima, Fabiano e sinha Vitória amparam-se mutuamente contra os inimigos da vida: o cansaço, a seca, a fome, os bichos carniceiros. E no centro da desgraça, em contraste e contra ela, constroem a esperança:

Pouco a pouco uma vida nova, ainda confusa, se foi esboçando. Acomodar-se-iam num sítio pequeno, o que parecia difícil a Fabiano, criado solto no mato. Cultivariam um pedaço de terra. Mudar-se-iam depois para uma cidade, e os meninos freqüentariam escolas, seriam diferentes deles. Sinha Vitória esquentava-se. Fabiano ria, tinha desejo de esfregar as mãos agarradas à boca do saco e à coronha da espingarda de pederneira. (p.153-4)

O narrador anota, em seguida: "Não sentia a espingarda, o saco, as pedras miúdas que lhe entravam nas alpercatas, o cheiro de carniças que empestavam o caminho". O que não existe para a consciência de Fabiano vem zelosamente recenseado pelo realista crítico, que acrescenta sem ênfase: "As palavras de sinha Vitória encantavam-no" (p.154).

Esse "encantar" significa simultaneamente "maravilhar" e "enfeitiçar". O poder mágico do "canto", das palavras, pode ser engano, ilusão, destruição da consciência, mas também estímulo para a luta. É a mesma ambiguidade que afeta a literatura.

Todo o final do parágrafo e do romance prossegue nessa corda bamba, entre o discurso utópico, enunciado no condicional, e a consciência crítica. O resultado é aquela esperança esclarecida, a "docta spes", de que fala Ernest Bloch, ou, na feliz síntese de Romain Rolland, transformada por Antonio Gramsci (1975, v.I, p.75; nota explicativa, v.IV, p.2510) em palavra de ordem: "pessimismo da inteligência, otimismo da vontade".

\section{Notas}

l Eis uma declaração precisa do autor: "O que me interessa é o homem, e homem daquela região aspérrima. Julgo que é a primeira vez que esse sertanejo aparece em literatura. Os romancistas do Nordeste têm pintado geralmente o homem do brejo. É 
o sertanejo que aparece na obra de José Américo e José Lins. Procurei auscultar a alma do ser rude e quase primitivo que mora na zona mais recuada do sertão, observar a reação desse espírito bronco ante o mundo exterior, isto é, a hostilidade do meio físico e da injustiça humana. Por pouco que o selvagem pense - e os meus personagens são quase selvagens - o que ele pensa merece anotação. Foi essa pesquisa psicológica que procurei fazer, pesquisa que os escritores regionalistas não fazem nem mesmo podem fazer, porque comumente não conhecem o sertão, não são familiares do ambiente que descrevem" (apud C. Ramos, 1979, p.125).

2 As próximas quatro citações do mesmo livro terão apenas a indicação do número da página.

3 Eis o que escreve Otto Maria Carpeaux (1968) acerca de Richard Hoggart, filho de operários, professor de literatura inglesa na Universidade de Birmingham: "Perante seus colegas de profissão, justificou sua ascensão em 1951, por um livro exaustivo sobre o poeta Auden".

4 Entrevista a Renovação, n.13, maio-jun./1944 (Arquivo Graciliano Ramos, IEB-USP).

5 J.-P. Sartre (1976, p.85), num depoimento de 1975, lembra, a propósito de Les mots: "Não creio que a história de um homem esteja inscrita em sua infância. Penso que há épocas muito importantes também em que as coisas se inserem: a adolescência, a juventude, e mesmo a idade madura. O que vejo mais claro em minha vida, é um corte que faz com que haja dois momentos quase completamente separados, a ponto de, estando no segundo, eu não me reconhecer mais muito bem no primeiro, isto é, antes da guerra e depois".

6 Leia-se este depoimento de um companheiro de prisão: "Ele [G.R.] contou-me que tinha vontade de escrever um romance sobre os flagelados do Nordeste. Vira coisas pelos sertões dos Estados nordestinos de arrebentar o coração - miséria, sofrimento, fome, 'vidas secas'... Massas humanas acuadas pela fome a assaltar fazendas, na marcha angustiosa em busca de pão. Vira coisas... Um dia contaria tudo. Agora, por último, via e vivia coisas negras. Não era mais um observador estranho aos acontecimentos. Tomava parte neles - era massa, era número... Vivia identificado, misturado com o povo, sentindo as suas dores, chorando as suas misérias, lutando - lutando sempre" (Cruz, 1938. p.9 - Arquivo G.R. IEB-USP).

7 Conservo a forma de acentuar do autor.

8 Perdi a referência desse estudo, de que só conheço as conclusões gerais, de segunda mão.

9 Existe ou existia uma distinção entre "sinha" e "sinhá", na dicção nordestina, o segundo termo, cerimonioso, reservado à camada dos proprietários.

10 "Para não ficar hidrófobo, [o cachorro] deve ter nome de peixe. [...] Para livrá-lo da tosse, põe-se-lhe ao pescoço um rosário feito com pedaços de sabugo de milho" (Cascudo, 1972, v.I, p.198).

11 As citações seguintes serão feitas sempre por essa edição, mencionando-se apenas a página.

12 Referindo-se à relação narrador-personagem em Vidas secas, escreve Bosi (1988, p.15): "[...] o que parece faltar na hora da empatia (por franco respeito às diferenças existenciais) resgata-se no acorde da simpatia intelectual” (Franco, 1939, p.37): “Graciliano 
Ramos adota uma outra forma de objetividade. É o que podemos chamar a forma patética".

13 Note-se a diferença entre essa adjetivação e a de $A$ terra dos meninos pelados: "pelados" descreve; "secas" interpreta.

14 Em “Batendo orelha!...”, Simões Lopes Neto (1961, p.237-40) constrói, em curtos parágrafos alternados, as histórias de um cavalo e de um homem, do nascimento à morte. Domesticação e educação também ali se confundem.

15 É a hipótese de A. G. Haudricourt: “as diferentes atitudes que guiam o homem na sua relação com a natureza que ele manipula e domina podem corresponder a outros tantos modos de dominar e manipular os seus semelhantes" (apud Ugo Fabietti, 1989, p.220). Ver também Jacques Barrau (1990).

16 "Na beira do rio haviam comido o papagaio que não sabia falar. Necessidade" (p.42); "Na beira do rio matara-o por necessidade, para sustentar a família" (p.52), recordam Fabiano e sinha Vitória.

17 "Novela y coloquio que pasó entre Cipión y Berganza, perros del hospital de la resurrección, que está en la ciudad de Valladolid, fuera de la Puerta del Campo, a quién comúnmente llaman los perros de Mahudes” [v.II, p.299-359]. La Bruyère (apud Auerbach, 1971, p.321).

18 A fórmula é de Terêncio: “sem Baco e Ceres, Vênus esfria”, isto é, sem o vinho e o pão, o amor esfria (ver discussão do problema em Bloch, 1991, p.84 ss).

\section{Referências}

ALAIN. Heureux agriculteurs. In: . Propos sur le bonheur. Paris: Gallimard, 1949.

ASSIS, M. de. A nova geração ( $1^{\circ}$ dez. 1879). In: Obra completa. Rio de Janeiro: Nova Aguilar S.A., 1986.

AUERBACH, E. Mimesis. Trad. George Bernard Sperber. São Paulo: Perspectiva, 1971.

BARRAU, J. Les hommes dans la nature: La domestication de la nature, ses corrélats sociaux et idéologiques. In: POIRIER, J. (Dir.) Histoire des maurs. I: Les coordonnées de l'homme et la culture matérielle. Paris: Gallimard, 1990. (Encyclopédie de La Pléiade).

BLOCH, E. Le principe espérance. Trad. Françoise Wuilmart. Paris: Gallimard, 1991. BOSI, A. Céu, inferno. São Paulo: Ática, 1988.

BRAGA, R. O conde e o passarinho. Rio de Janeiro: Livraria José Olympio Editora, 1936.

BROUÉ, P. Os processos de Moscovo. Trad. Rodrigo Manuel Ferreira Neves. Lisboa: Livraria Morais Editora, 1966.

BRUNO, H. Estudos de literatura brasileira. Rio de Janeiro: Ed. O Cruzeiro, 1957.

CAMUS, A. Réflexions sur la guillotine. In: KOSTLER, A.; CAMUS, A. Réflexions sur la peine capitale. Paris: Calmann-Lévy, 1957.

CARPEAUX, O. M. A literatura e os alfabetizados. In: Vinte e cinco anos de literatura. Rio de Janeiro: Civilização Brasileira, 1968. 
CASCUDO, L. da C. Dicionário do folclore brasileiro. Brasília: INL, 1972, v.I. p.198.

CRUZ, H. T. Escritor não é bicho do outro mundo. Moços, Curitiba, dez. 1938. p.9.

DECHAMBRE, E. Les chiens. Paris: PUF, 1971. (Col. “Que sais-je?”, v.552).

FABIETTI, U. Vegetal. In: ROMANO, R. (Org.) Enciclopédia Einaudi, v.16: Homo-domesticação. Cultura Material. s. 1.: Imprensa Nacional, Casa da Moeda, 1989.

FRANCO, A. A. de M. Idéia e tempo. Crônica e crítica. São Paulo: Cultura Moderna, 1939

FURTH, P.-P. Histoires bêtes, histoires de bêtes. Europe, 54 e année, n.561-562, p.94, jan./fév. 1976.

GRAMSCI, A. Quaderni del carcere. Edizione critica dell'Istituto Gramsci. A cura de Valentino Gerratana. Torino: Giulio Einaudi Editore, 1975.

Maquiavel, a política e o estado moderno. Trad. de Luiz Mário Gazzaneo. Rio

de Janeiro: Civilização Brasileira, 1978.

JANKÉLÉVITCH, V. L'ironie. Paris: Flammarion, 1987.

LIMA, Y. D.; REIS, Z. C. (Coord.) Catálogo de manuscritos do Arquivo Graciliano Ramos. São Paulo: Edusp, 1992.

LOPES NETO, S. Contos gauchescos e lendas do Sul. Edição crítica de Aurélio Buarque de Holanda. Porto Alegre: Globo, 1961.

MELO NETO, J. C. Morte e vida severina (Auto de natal pernambucano). In: __. Poesias completas (1940-1965). 2.ed. Rio de Janeiro: Livraria José Olympio, 1975 p. p.210-11.

MICHELET, J. Le peuple. Paris: Julliard, 1965.

PRATOLINI, V. Ofício de vagabundo. Lisboa: Ed. Livros do Brasil, s. d.

RAMOS, G. Vidas secas. Rio de Janeiro: José Olympio, 1953a.

. Caetés. Rio de Janeiro: Livraria José Olympio, 1953b.

S. Bernardo. Rio de Janeiro: Livraria José Olympio, $1953 \mathrm{c}$.

. Memórias do cárcere. Rio de Janeiro: José Olympio, 1953-1954. v.II, cap.8.

. Viagem. Rio de Janeiro: José Olympio, 1955.

. Linhas tortas. São Paulo: Martins, 1967.

lização, 1979.

. Mestre Graciliano. Confirmação humana de uma obra. Rio de Janeiro: Civi-

. Cartas. Rio de Janeiro: Record, 1980.

. Viventes das Alagoas. São Paulo: Martins, s. d.

RAMOS, R. Lembrança de Graciliano. In: GARBUGLIO, J. C. et al. Graciliano Ramos. São Paulo: Ática, 1987.

ROSA, J. G. Grande sertão: veredas. 5.ed. Rio de Janeiro: José Olympio, 1967.

SAAVEDRA, M. C. Novelas ejemplares. 12.ed. Harry Sieber Ed. Madrid: Cátedra, 1990.

SARTRE, J.-P. Situations, X: Politique et autobiographie. Paris: Gallimard, 1976.

SILVEIRA, J.; MORAES NETO, G. Hitler/Stalin. O pacto maldito. Rio de Janeiro: Record, 1989. 
RESUMO - Vidas secas (1938) é o último romance de Graciliano Ramos, escrito depois da experiência do autor nos cárceres do Estado Novo, experiência por ele mesmo julgada essencial para a elaboração do livro. O artigo começa pela discussão acerca do sentido das exigências éticas e estéticas do romancista. Procura descrever a organização do romance a partir da combinação de contos, originalmente autônomos. Examina em seguida o episódio "Baleia", onde se discute o problema da domesticação e da educação. Termina com a análise da tensão entre a fala da utopia e o realismo crítico.

PALAVRAS-CHAVE: Literatura e experiência, Ética e estética, Conto e romance, Domesticação e educação, Utopia e realismo crítico.

ABSTRACT - Vidas secas (1938) is Graciliano Ramos`s last novel which was written after the author's experiences in the prisions of the Estado Novo. This experience was judged essential to the organization of the book by the author himself. The article begins with a discussion of the sense of ethical and aesthetic exigencies of the novelist. It endeavours to describe the organization of the novel, beginning with the combination of short stories which were originally autonomous works. Then it examines the episode "Baleia", where the problems of domestication and rearing are discussed. It finishes with the analysis of the tension between the talk of Utopia and critical realism.

KEYWORDS: Literature and experience, Ethica and aesthetic, Novel, Domestication and rearing, Utopia and critical realism.

Zenir Campos Reis é professor de Literatura Brasileira na Faculdade de Filosofia, Letras e Ciências Humanas da USP. @ - zenir-reis@uol.com.br

Recebido em 26.6.2012 e aceito em 4.7.2012. 